
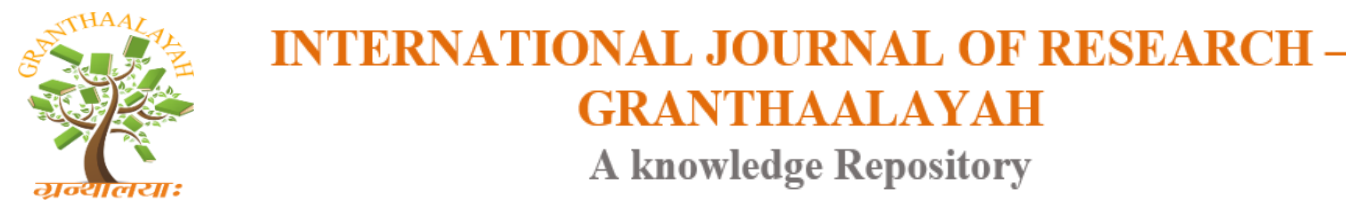

Management

\title{
A COMPARATIVE STUDY ON SATISFACTION OF CUSTOMERS OF PUBLIC SECTOR AND PRIVATE SECTOR BANKS TOWARDS E BANKING IN TIRUNELVELI DISTRICT
}

\author{
K.Thanga Glara ${ }^{* 1}$, Dr. C. Eugine Franco ${ }^{2}$ \\ ${ }^{* 1}$ Assistant Professor in Commerce, St. Xavier's (Autonomous) College, Palayamkottai, India \\ 2 Associate Professor, PG \& Research Department of Commerce, St. Xavier's (Autonomous) \\ College, Palayamkottai, India
}

DOI: https://doi.org/10.29121/granthaalayah.v5.i5(SE).2017.1967

\begin{abstract}
The last two decades in the banking industry has seen many developments to face the competition among its competitors. Technology is one field that banking industry focuses on for this competition. Nowadays e-banking is the popular technology used by banks. E-banking is the outcome of technological innovations and competition. The customers' satisfaction is also very important to face the challenges for the banks to cope up with other banks. Hence this paper focuses on the satisfaction level of customers towards e-banking services provided by Public and Private Sector banks in Tirunelveli District. This study is limited to Tirunelveli area only, Tamil Nadu. The objectives of this study are to find out the factors influencing in the adoption of Ebanking provided by public and private sector banks, identify the level of satisfaction of customers of public and private sector banks towards their usage of E-banking. Convenience sampling method have adopted for this study. The primary data were collected from questionnaire method. From the analysis, it is found that with regard to satisfaction in ATM services, the customers of both sectors of banks are equally satisfied.

Also the customers are satisfied with the e-banking services provided by private sector banks. It is suggested that ease of use is the major factor to induce the customers to adopt e-banking. Therefore banks should maintain its applications more user friendly and up to date. ATMs receive the higher attraction among the e-banking channels. Banks must pay attention and plan to make the ATMs as the key distribution channel for all kinds of banking transactions.
\end{abstract}

Keywords: E-Banking; Satisfaction; ATM; Public Sector Bank; Private Sector Bank.

Cite This Article: K.Thanga Glara, and Dr. C. Eugine Franco. (2017). "A COMPARATIVE STUDY ON SATISFACTION OF CUSTOMERS OF PUBLIC SECTOR AND PRIVATE SECTOR BANKS TOWARDS E BANKING IN TIRUNELVELI DISTRICT.” International Journal of Research - Granthaalayah, 5(5)SE, 53-62. 


\section{Introduction}

Banks in India need to be admired on the enclosure of technology in a large way in their day-today operations. The last two decade has seen many constructive developments in the Indian Banking Sector. Nowadays e-banking is the popular technology used by banks. E-Banking means any user with a personal computer and a browser can get connected to his bank's website to perform any of the virtual banking functions. E-banking is the outcome of technological innovations and competition. In fact, banks have been using electronic and telecommunication networks for delivering a wide range of value added products and services. As a part of their ebanking initiatives banks offered the following new delivery channels to customer's Automated Teller Machines (ATM)/ Cash Dispensers (CD), Phone banking, Internet banking and Mobile banking. Banks used e-banking as mechanism to fight fierce competition that existed in the market and also to retain the customers base they had customer's response to e-banking was enthusiastic and followed predicted path of Technology Adoption Life Cycle models (Shreyan at 2002).

\section{Statement of the Problem}

In the competitive environment of the post liberalization era, financial sector reforms have significantly relaxed the market. Banks has evolved new products and services to attract the customers through innovative technological delivery channels. There are also several special operations which give an intensive marketing push to increase the customer base and usage of technological innovative banking services. For Indian Banks, there is a wide market potential amongst e-banking. The demand for e-banking is necessitate by the growing e-commerce transactions and the paradigm shift in banking led by technology. From the perspective of both users and providers, E-Banking is cost effective, quick and convenient. Hence, it is needed to identify the reason why customer's preference e-banking.

\section{Objectives of the Study}

1) To find out the factors influencing in the adoption of E-banking provided by public and private sector banks.

2) To identify the level of satisfaction of customers of public and private sector banks towards their usage of E-banking.

3) To offer Suggestions

\section{Scope of the Study}

The study aims to find out the perception and preference of customers towards e-banking offered by Public and Private sector banks. This study also aims at measuring the satisfaction of the customers and offer suitable suggestions to solve the problems. This study also compares the perception and preference of customers towards e-banking services offered by public and private sector banks in Tirunelveli district. 


\section{Research Methodology}

For this research both primary and secondary data were collected. Primary data were collected from the customers of public sector and private sector banks using e-banking and it was collected through well-defined and well-framed questionnaire. Snowball sampling method was used for selecting sample respondents. Four hundred and sixty one respondents were selected. The secondary data were collected from various websites, books, journals and magazines.

\section{Analysis and Interpretation of Data}

Demographic profile is one of the important variables to determine the usage and satisfaction of the respondents. The following tables clearly explain about the demographic profile of the respondents in the study area.

Table 1: Gender wise classification of the respondents

\begin{tabular}{|c|c|c|c|c|}
\hline \multicolumn{5}{|c|}{ Gender * Type of Bank Cross Tabulation } \\
\hline & & \multicolumn{2}{|l|}{ Type of Bank } & \multirow{2}{*}{ Total } \\
\hline & & Public Sector Bank & Private Sector Bank & \\
\hline \multirow{4}{*}{ Gender } & \multirow{2}{*}{ Male } & 117 & 163 & 280 \\
\hline & & $52.0 \%$ & $69.1 \%$ & $60.7 \%$ \\
\hline & \multirow{2}{*}{ Female } & 108 & 73 & 181 \\
\hline & & $48.0 \%$ & $30.9 \%$ & $39.3 \%$ \\
\hline \multirow{2}{*}{\multicolumn{2}{|c|}{ Total }} & 225 & 236 & 461 \\
\hline & & $100.0 \%$ & $100.0 \%$ & $100.0 \%$ \\
\hline
\end{tabular}

From the above table it is clear that, out of 461 respondents majority 60.7 percent are male respondents and rest of the 39.3 percent of the respondents are female respondents.

Out of 225 public sector bank's respondent's majority 52 percent are male respondents and rest of the 48 percent are female respondents.

Out of 236 private sector bank's respondent's majority 69.1 percent are male respondents and rest of the 30.9 percent are female respondents.

Table 2: Age wise classification of the respondents

\begin{tabular}{|c|c|c|c|c|}
\hline \multicolumn{5}{|c|}{ Age * Type of Bank Cross Tabulation } \\
\hline & & \multicolumn{2}{|l|}{ Type of Bank } & \multirow{2}{*}{ Total } \\
\hline & & Public Sector Bank & Private Sector Bank & \\
\hline \multirow{6}{*}{ Age } & \multirow{2}{*}{18 - 30 Years } & 103 & 92 & 195 \\
\hline & & $45.8 \%$ & $39.0 \%$ & $42.3 \%$ \\
\hline & \multirow{2}{*}{30 - 50 Years } & 80 & 80 & 160 \\
\hline & & $35.6 \%$ & $33.9 \%$ & $34.7 \%$ \\
\hline & \multirow{2}{*}{ Above 50 Years } & 42 & 64 & 106 \\
\hline & & $18.7 \%$ & $27.1 \%$ & $23.0 \%$ \\
\hline
\end{tabular}




\section{Total}

\begin{tabular}{|l|l|}
\hline 225 & 236 \\
\hline $100.0 \%$ & $100.0 \%$ \\
\hline
\end{tabular}

From the table, out of 461 respondents majority 42.3 percent of the respondents are belong to the age group of 18-30 years, 34.7 percent of the respondents are belong to the age group of 3050 and rest of the 23 percent of the respondents are belong to the age group of above 50 years.

Out of 225 public sector bank's respondents majority 45.8 percent of the respondents are belong to the age group of 18-30 years, 35.6 percent of the respondents are belong to the age group of 30-50 and rest of the 18.7 percent of the respondents are belong to the age group of above 50years.

Out of 236 private sector bank's respondents majority 39 percent of the respondents are belong to the age group of 18-30 years, 33.9 percent of the respondents are belong to the age group of $30-50$ and rest of the 27.1 percent of the respondents are belong to the age group of above 50years.

Table 3: Education wise classification of the respondents

\begin{tabular}{|c|c|c|c|c|}
\hline \multicolumn{5}{|c|}{ Education * Type of Bank Cross Tabulation } \\
\hline & & \multicolumn{2}{|l|}{ Type of Bank } & \multirow[b]{2}{*}{ Total } \\
\hline & & Public Sector Bank & Private Sector Bank & \\
\hline \multirow{8}{*}{ Education } & \multirow{2}{*}{ School Level } & 24 & 14 & 38 \\
\hline & & $10.7 \%$ & $5.9 \%$ & $8.2 \%$ \\
\hline & \multirow{2}{*}{ U.G Level } & 50 & 84 & 134 \\
\hline & & $22.2 \%$ & $35.6 \%$ & $29.1 \%$ \\
\hline & \multirow{2}{*}{ P.G Level } & 67 & 67 & 134 \\
\hline & & $29.8 \%$ & $28.4 \%$ & $29.1 \%$ \\
\hline & \multirow{2}{*}{ Professional } & 84 & 71 & 155 \\
\hline & & $37.3 \%$ & $30.1 \%$ & $33.6 \%$ \\
\hline \multirow{2}{*}{\multicolumn{2}{|c|}{ Total }} & 225 & 236 & 461 \\
\hline & & $100.0 \%$ & $100.0 \%$ & $100.0 \%$ \\
\hline
\end{tabular}

From the above table, it is clear that, out of 461 respondents majority 33.6 percent of the respondents are completed professional courses, 29.1 percent of the respondents are under graduates, another 29.1 percent of the respondents are post graduates and rest of the 8.2 percent of the respondents are completed up to school level.

Out of 225 public sector bank's respondents majority 37.3 percent of the respondents are completed professional courses, 29.8 percent of the respondents are post graduates, 22.2 percent of the respondents are under graduates and rest of the 10.7 percent of the respondents are completed up to school level.

Out of 236 private sector bank's respondent's majority 35.6 percent of the respondents are under graduates, 30.1 percent of the respondents are completed professional courses, 28.4 percent of 
the respondents are post graduates and rest of the5.9 percent of the respondents are completed upto school level.

Table 4: Marital status of the respondents

\begin{tabular}{|c|c|c|c|c|}
\hline \multicolumn{5}{|c|}{ MARITAL STATUS * Type of Bank Cross Tabulation } \\
\hline & & \multicolumn{2}{|l|}{ Type of Bank } & \multirow[b]{2}{*}{ Total } \\
\hline & & Public Sector Bank & Private Sector Bank & \\
\hline \multirow{4}{*}{ MARITAL STATUS } & \multirow{2}{*}{ Single } & 63 & 42 & 105 \\
\hline & & $28.0 \%$ & $17.8 \%$ & $22.8 \%$ \\
\hline & \multirow{2}{*}{ Married } & 162 & 194 & 356 \\
\hline & & $72.0 \%$ & $82.2 \%$ & $77.2 \%$ \\
\hline \multirow{2}{*}{\multicolumn{2}{|c|}{ Total }} & 225 & 236 & 461 \\
\hline & & $100.0 \%$ & $100.0 \%$ & $100.0 \%$ \\
\hline
\end{tabular}

From the above table, it is clear that, out of 461 respondents majority 77.2 percent of the respondents are married and rest of the 22.8 percent of the respondents are single.

Out of 225 public sector bank's respondent's majority 72 percent of the respondents are married and rest of the 28 percent of the respondents are single.

Out of 236 private sector bank's respondent's majority 82.2 percent of the respondents are married and rest of the 17.8 percent of the respondents are single.

Table 5: Occupation of the respondents

\begin{tabular}{|c|c|c|c|c|}
\hline \multicolumn{5}{|c|}{ Occupation * Type of Bank Cross Tabulation } \\
\hline & & \multicolumn{2}{|l|}{ Type of Bank } & \multirow[b]{2}{*}{ Total } \\
\hline & & Public Sector Bank & Private Sector Bank & \\
\hline \multirow{12}{*}{ Occupation } & \multirow{2}{*}{ Government Employee } & 43 & 34 & 77 \\
\hline & & $19.1 \%$ & $14.4 \%$ & $16.7 \%$ \\
\hline & \multirow{2}{*}{ Private Employee } & 52 & 67 & 119 \\
\hline & & $23.1 \%$ & $28.4 \%$ & $25.8 \%$ \\
\hline & \multirow{2}{*}{ Business } & 27 & 41 & 68 \\
\hline & & $12.0 \%$ & $17.4 \%$ & $14.8 \%$ \\
\hline & \multirow{2}{*}{ Professional } & 54 & 46 & 100 \\
\hline & & $24.0 \%$ & $19.5 \%$ & $21.7 \%$ \\
\hline & \multirow{2}{*}{ Student } & 24 & 26 & 50 \\
\hline & & $10.7 \%$ & $11.0 \%$ & $10.8 \%$ \\
\hline & \multirow{2}{*}{ Housewife } & 25 & 22 & 47 \\
\hline & & $11.1 \%$ & $9.3 \%$ & $10.2 \%$ \\
\hline \multirow{2}{*}{\multicolumn{2}{|c|}{ Total }} & 225 & 236 & 461 \\
\hline & & $100.0 \%$ & $100.0 \%$ & $100.0 \%$ \\
\hline
\end{tabular}


From the above table, it is reveals that, out of 461 respondents majority 25.8 percent of the respondents are private employees, 21.7 percent of the respondents are professional, 16.7 percent of the respondents are government employees, 14.8 percent of the respondents are doing business, 10.8 percent of the respondents are students and rest of the 10.2 percent of the respondents are housewife.

Out of 225 public sector bank's respondents majority 24 percent of the respondents are professional, 23.1 percent of the respondents are private employees, 19.1 percent of the respondents are government employees, 12 percent of the respondents are doing business, 11.1 percent of the respondents are housewife and rest of the 10.7 percent of the respondents are students.

Out of 236 private sector bank's respondent's majority 28.4 percent of the respondents are private employees, 19.5 percent of the respondents are professional, 17.4 percent of the respondents are doing business, 14.4 percent of the respondents are government employees, 11 percent of the respondents are students and rest of the 9.3 percent of the respondents are housewife.

Table 6: Income wise classification of the respondents

\begin{tabular}{|c|c|c|c|c|c|c|}
\hline \multicolumn{7}{|c|}{ Monthly Income * Type of Bank Cross Tabulation } \\
\hline & & \multicolumn{4}{|c|}{ Type of Bank } & \multirow[b]{2}{*}{ Total } \\
\hline & & $\begin{array}{l}\text { Public } \\
\text { Bank }\end{array}$ & Sector & $\begin{array}{l}\text { Private } \\
\text { Bank }\end{array}$ & Sector & \\
\hline \multirow{8}{*}{$\begin{array}{l}\text { Monthly } \\
\text { Income }\end{array}$} & \multirow{2}{*}{ 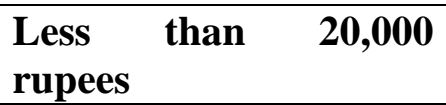 } & 66 & & 40 & & 106 \\
\hline & & $29.3 \%$ & & $16.9 \%$ & & $23.0 \%$ \\
\hline & \multirow{2}{*}{20,000 to 40,000 rupees } & 64 & & 67 & & 131 \\
\hline & & $28.4 \%$ & & $28.4 \%$ & & $28.4 \%$ \\
\hline & \multirow{2}{*}{40,000 to 60,000 rupees } & 55 & & 77 & & 132 \\
\hline & & $24.4 \%$ & & $32.6 \%$ & & $28.6 \%$ \\
\hline & \multirow{2}{*}{$\begin{array}{l}\begin{array}{l}\text { More than } \\
\text { rupees }\end{array} \\
\end{array}$} & 40 & & 52 & & 92 \\
\hline & & $17.8 \%$ & & $22.0 \%$ & & $20.0 \%$ \\
\hline \multirow{2}{*}{\multicolumn{2}{|c|}{ Total }} & 225 & & 236 & & 461 \\
\hline & & $100.0 \%$ & & $100.0 \%$ & & $100.0 \%$ \\
\hline
\end{tabular}

From the above table, it is clear that, out of 461 respondents majority 28.6 percent of the respondents are earn Rs. 400000-60000 per month, 28.4 percent of the respondents are earn Rs. 20000-40000 per month, 23 percent of the respondents are earn less than Rs. 20000 per month and rest of the 20 percent of the respondents are earn more than Rs. 60000 per month.

Out of 225 public sector bank's respondents majority 29.3 percent of the respondents are earn less than Rs. 20000 per month, 28.4 percent of the respondents are earn Rs. 20000-40000 per month, 24.4 percent of the respondents are earn less than Rs. 40000-60000 per month and rest of the 17.8 percent of the respondents are earn more than Rs. 60000 per month. 
Out of 236 private sector bank's respondents majority 32.6 percent of the respondents are earn Rs. 40000-60000 per month, 28.4 percent of the respondents are earn Rs. 20000-40000 per month, 22 percent of the respondents are earn more than Rs.60000 per month and rest of the 16.9 percent of the respondents are earn less than Rs. 20000 per month.

Table 7: Factors induced to use e-banking

\begin{tabular}{|c|c|c|c|c|c|}
\hline \multicolumn{6}{|c|}{ Factors Induced * Type of Bank Cross Tabulation } \\
\hline & & & \multicolumn{2}{|c|}{ Type of Bank } & \multirow[b]{2}{*}{ Total } \\
\hline & & & $\begin{array}{l}\text { Public } \\
\text { Sector } \\
\text { Bank } \\
\end{array}$ & $\begin{array}{l}\text { Private } \\
\text { Sector } \\
\text { Bank } \\
\end{array}$ & \\
\hline \multirow{8}{*}{ Factors Induced } & \multirow{2}{*}{$\begin{array}{l}\text { Reduced time of } \\
\text { transaction }\end{array}$} & Count & 48 & 70 & 118 \\
\hline & & $\%$ within Type of Bank & $21.3 \%$ & $29.7 \%$ & $25.6 \%$ \\
\hline & \multirow{2}{*}{$\begin{array}{l}\text { Cost } \\
\text { effectiveness }\end{array}$} & Count & 39 & 55 & 94 \\
\hline & & $\%$ within Type of Bank & $17.3 \%$ & $23.3 \%$ & $20.4 \%$ \\
\hline & \multirow{2}{*}{ Ease of use } & Count & 96 & 78 & 174 \\
\hline & & $\%$ within Type of Bank & $42.7 \%$ & $33.1 \%$ & $37.7 \%$ \\
\hline & \multirow{2}{*}{$\begin{array}{l}\text { Technology } \\
\text { savvy }\end{array}$} & Count & 42 & 33 & 75 \\
\hline & & $\%$ within Type of Bank & $18.7 \%$ & $14.0 \%$ & $16.3 \%$ \\
\hline \multirow{2}{*}{\multicolumn{2}{|c|}{ Total }} & Count & 225 & 236 & 461 \\
\hline & & $\%$ within Type of Bank & $100.0 \%$ & $100.0 \%$ & $100.0 \%$ \\
\hline
\end{tabular}

From the above table, it is clear that, out of 461 respondents majority 37.7 percent of the respondents says that ease of use is the motivating factor for availing e-banking services, 25.6 percent of the respondents says that reduced time of transaction is the motivating factor for availing e-banking services, 20.4 percent of the respondents says that cost effectiveness is the motivating factor for availing e-banking services and rest of the 16.3 percent of the respondents says that technology savvy is the motivating factor for availing e-banking services.

Out of 225 public sector bank's respondents majority 42.7 percent of the respondents says that ease of use is the motivating factor for availing e-banking services, 21.3 percent of the respondents says that reduced time of transaction is the motivating factor for availing ebanking services, 18.7 percent of the respondents says that technology savvy is the motivating factor for availing e-banking services and rest of the 17.3 percent of the respondents says that cost effectiveness is the motivating factor for availing e-banking services.

Out of 236 private sector bank's respondents majority 33.1 percent of the respondents says that ease of use is the motivating factor for availing e-banking services, 29.7 percent of the respondents says that reduced time of transaction is the motivating factor for availing ebanking services, 23.3 percent of the respondents says that cost effectiveness is the motivating factor for availing e-banking services and rest of the 14 percent of the respondents says that technology savvy is the motivating factor for availing e-banking services. 
Table8: Satisfaction of customers

\begin{tabular}{|l|l|l|l|l|l|l|}
\hline $\begin{array}{l}\text { TYPES OF } \\
\text { BANK }\end{array}$ & \multicolumn{3}{|l|}{ Public sector Bank } & \multicolumn{3}{l|}{ Private sector Bank } \\
\hline SATISFACTION & Minimum & Maximum & Mean & Minimum & Maximum & Mean \\
\hline ATM Services & 3 & 5 & 3.76 & 3 & 5 & 3.78 \\
\hline $\begin{array}{l}\text { Internet Banking } \\
\text { Services }\end{array}$ & 2 & 4 & 2.83 & 2 & 5 & 3.39 \\
\hline $\begin{array}{l}\text { Telephone } \\
\text { Banking Services }\end{array}$ & 1 & 4 & 2.17 & 2 & 4 & 3.01 \\
\hline $\begin{array}{l}\text { Mobile Banking } \\
\text { Services }\end{array}$ & 1 & 3 & 2.32 & 2 & 4 & 3.53 \\
\hline
\end{tabular}

The table reveals that mean score of respondents on satisfaction on banking services. The mean score of 3.76 with the range of 3 and 5 for public sector banks and 3.78 with a range of 3 and 5 on ATM services reveals that the customers are equally satisfied with both type of banks. The mean score of 2.83 with the range of 2 and 4 for public sector banks and 3.39 with a range of 2and 5 on internet banking reveals that the customers are better satisfied on internet banking in private sector than public sector banks. The mean score of 2.17 with the range of 1 and 4 for public sector banks and 3.01with the range of 2 and 4 on telephone banking reveals that the customers comparatively are satisfied in private sector banks. The mean score of 2.32 with the range of 1 and 3 for public sector banks and 3.53 with the range of 2 and 4 on Mobile banking reveals that the customers of public sector banks are less satisfied than private sector banks on mobile banking services. It is understood from the analysis that customers are satisfied with the services provided by private sector banks.

\section{Findings of the Study}

- In both public and private sector banks male respondents are dominated.

- In both public and private sector banks majority of the respondents belong to the age group of 18-30 years.

- In public sector banks majority of the respondents have completed their professional courses and in private sector banks majority of the respondents are under graduates.

- In both public and private sector banks majority of the respondents are married.

- In public sector banks majority of the respondents are professional and in private sector banks majority of the respondents are private employees.

- In public sector banks majority of the respondents are earn less than Rs. 20000 per month and in private sector banks majority of the respondents are earn Rs. 40000-60000 per month.

- In both public and private sector banks majority of the respondents says that ease of use is the motivating factor for availing e-banking services

- The customers of both public and private sector banks are equally satisfied with ATM services provided.

- On the whole customers are satisfied with the services provided by private sector banks. 


\section{Suggestions}

- Public Sector banks must give individual attention and proper response to customers in providing information whereas the level of responsiveness is high in the private sector banks. This will help many customers to rely on public sector banks for their banking needs.

- Banks must ensure to their customers that their service is competitive. Many customers feel that the privacy and security features are to be enriched. So banks must concentrate further on security and withhold their customers and improve them more.

- Ease of use is the major factor to induce the customers to adopt e-banking. Therefore banks should maintain its applications more user friendly and up to date.

- ATMs receive the higher attraction among the e-banking channels. Banks must pay attention and plan to make the ATMs as the key distribution channel for all kinds of banking transactions.

\section{Conclusion}

Internet adoption among Indians has been increasing over the last two decade. Indian banks have also risen to the occasion by offering new delivery channel which has become available to Indian customers. Private sector banks are quite successful in satisfying their customer's needs. But public sector banks are still need to put more efforts to make this sector to survive in the present world of e-banking competition.

\section{References}

[1] Fox, S. (2005). The state of online banking.In Pew Internet \&American Life Project, Pew Research Center. Retrieved on April, 2017 from http://www.pewinternet.org/pdfs/PIP_Online_Banking_2005.pdf.

[2] Golden, S. A. R. (2015). Regional Imbalance affecting quality of e-banking services with special reference to Tuticorin District- An Analysis. International Journal of Research, 2(3), 788-799.

[3] Golden, S. A. R., \& Regi, S. B. (2015). Satisfaction of Customers towards User Friendly Technological Services offered by Public and Private Sector banks at Palayamkottai, Tirunelveli District. International Journal of Research, 2(3), 775-787.

[4] Khalil, M. N., \& Pearson, J. M. (2007). The Influence of Trust onInternet Banking Acceptance. Journal of Internet Banking andCommerce, 12(2) Retrieved on 09 Apr 2017 from http://www.arraydev.com/commerce/jibc/2007-08/Md_Nor_Final_PDF\%20Ready.pdf.

[5] Mohan, R. (2004). Indian Banking and e-Security. Reserve Bank ofIndia Bulletin, November 2004, 1029-1033. Mumbai: Reserve Bankof India.

[6] Nitsure, R. R. (2003). E-banking: Challenges and Opportunities.Economic and Political Weekly, $38(51 \& 52), 10$ pages.

[7] Perumal, V. P. (2004). Internet Banking: Boon or Bane ?. Journal ofInternet Banking and Commerce, 9(3) Retrieved April 22, 2017 from http://www.arraydev.com/commerce/JIBC/200412/Perumal.HTM.

[8] Regi, S. B., \& Golden, S. A. R. (2014). Customer Preference Towards Innovative Banking Practices Available In State Bank Of India At Palayamkottai. Sankhya International Journal Of Management And Technology, 3(11 (A)), 31-33. 
[9] Regi, S. B., Golden, S. A. R., \& Franco, C. E. (2014). A STUDY ON IMPACT OF INFORMATION TECHNOLOGY (IT) IN MODERN BANKING SECTOR. Golden Research Thoughts, 3(9), 1-4.

[10] Regi, S. B., Golden, S. A. R., \& Franco, C. E. (2014). EMPLOYEE PERCEPTION TOWARDS EFFECTIVENESS OF HR PRACTICES IN PUBLIC SECTOR BANKS IN TIRUNELVELI DISTRICT. Tactful Management Research Journal, 2(6), 1-4.

[11] Shreyan, S., Chhatwal, S. S., Yahyabhoy, T. M., \&Heng, Y. C.(2002). Dynamics Of Innovation In E-banking. In ECIS, Retrievedon December 28, 2016 from http://is2.lse.ac.uk/asp/aspecis/20020136.pdf.

[12] Singh, S., Chhatwal, S. S., \&Heng, Y. C. (2002). Dynamics ofInnovation in E-Banking. In Proceeding of ECIS 2002 June 6, Gdansk, Poland pp. 1527-1537. 